\title{
Plasminogen activators in alcoholic cirrhosis: demonstration of increased tissue type and urokinase type activator
}

\author{
NUALA A BOOTH, JUDITH A ANDERSON, BRUCE BENNETT \\ From the Department of Medicine, University of Aberdeen, Aberdeen Royal Infirmary, Foresterhill, \\ Aberdeen $A B 92 Z B$
}

SUMMARY Plasma samples from patients with alcoholic cirrhosis were analysed for plasminogen activators and for inhibitors of the fibrinolytic system. Plasminogen activator activity was considerably increased in patients' plasma compared with normal. Immunochemical characterisation of these plasminogen activators showed that they included both tissue type and urokinase type plasminogen activator. The major inhibitor of plasmin, $\alpha_{2}$-antiplasmin, was decreased in the patients, but no evidence for the generation of plasmin was found.

It has been known for many years that abnormally enhanced fibrinolysis is responsible for some of the haemorrhagic problems associated with hepatic cirrhosis.' ' In 1964 Fletcher et $a^{3}$ showed that the in vivo clearance rate for plasma plasminogen activator after nicotinic acid injection was four times slower in cirrhotic patients than in normal controls. They suggested that abnormal fibrinolysis in cirrhosis may be due to failure of hepatic clearance mechanisms for plasminogen activator.

The primary plasma inhibitor of plasmin $\alpha_{2-}$ antiplasmin is decreased in liver disease. ${ }^{4}$ Histidine rich glycoprotein, which is an inhibitor of fibrinolysis, ${ }^{5}$ is similarly affected. ${ }^{67}$ These observations provide additional or alternative explanations for the fibrinolytic activity seen in hepatic cirrhosis.

The technique of sodium dodecyl sulphatepolyacrylamide gel electrophoresis (SDS-PAGE), followed by zymography on fibrin agarose layers, ${ }^{\text {. }}$ has been applied to the analysis of plasma samples for plasminogen activators." Using this approach, together with other methods, we have studied the fibrinolytic system in a group of patients with alcoholic cirrhosis. The aims of the study were: $(a)$ to examine the nature of plasminogen activators responsible for increased fibrinolytic activity in cirrhosis; and $(b)$ to investigate the possibility that plasmin generation occurs in the circulation and might, by consuming fibrinolytic inhibitors, be responsible for the reduced levels of these inhibitors seen in this disorder.

Accepted for publication 6 April 1984

\section{Material and methods}

Blood samples were collected into $0 \cdot 1$ volume of $0 \cdot 13 \mathrm{M}$ sodium citrate and immediately cooled on ice. Platelet poor plasma was prepared by centrifugation at $1200 \mathrm{~g}$ for $15 \mathrm{~min}$ at $4^{\circ} \mathrm{C}$. Plasma samples were stored at $-70^{\circ} \mathrm{C}$.

Clottable fibrinogen was measured by a modification ${ }^{10}$ of the method of Ratnoff and Menzie." Plasminogen, $\alpha_{2}$-antiplasmin, antithrombin III, histidine rich glycoprotein, $\alpha_{1}$-antitrypsin, $\alpha_{2-}$ macroglobulin, and $\mathrm{Cl}$ inactivator were determined by electroimmunoassay. ${ }^{12}$ Antiserum to histidine rich glycoprotein was kindly provided by $\mathrm{Dr} N$ Heimburger, Behringwerke AG. Crossed immunoelectrophoresis against antiserum to $\alpha_{2-}$ antiplasmin was performed as described previously. ${ }^{1314}$ In some studies purified human plasminogen 15 was incorporated into the agarose gel in the first dimension at a final concentration of $0 \cdot 1$ $\mathrm{mg} / \mathrm{ml}$ to distinguish between plasminogen binding and non-binding forms of $\alpha_{2}$-antiplasmin. ${ }^{16}$

The overall fibrinolytic activity of plasma was assessed by assay of unfractionated plasma on plasminogen replete fibrin plates. ${ }^{14} 17$ The euglobulin clot lysis time was measured as described previously. ${ }^{18}$

Plasma plasminogen activators were fractionated on lysine-Sepharose, essentially as described by Radcliffe and Heinze. ${ }^{19}$ Plasma samples $(2 \mathrm{ml})$ were loaded on to columns $(0.8 \times 3.5 \mathrm{~cm})$, equilibrated with $50 \mathrm{mM}$ Tris, $1 \mathrm{mM}$ benzamidine, $1 \mathrm{mM}$ edetic acid $\mathrm{pH} 7 \cdot 5$, and eluted with $1 \cdot 5 \mathrm{M} \mathrm{NaCl}$ followed by 
$0.2 \mathrm{M}$ e-aminocaproic acid, each dissolved in this buffer.

SDS-PAGE with zymography on fibrin agarose layers was by the method of Granelli-Piperno and Reich. ${ }^{8}$ Samples $(10 \mu \mathrm{l})$ were prepared for SDSPAGE by incubation with $10 \mu \mathrm{l}$ of $8 \mathrm{M}$ urea, $4 \%$ sodium dodecyl sulphate, $40 \mathrm{mM}$ iodoacetamide, $0.2 \mathrm{M}$ Tris $\mathrm{pH} 8.0$, for $30 \mathrm{~min}$ at $37^{\circ} \mathrm{C}$ and then made $10 \%$ with respect to glycerol. They were applied to a Laemmli ${ }^{20}$ gel (separating and stacking gels were $10 \%$ and $3 \%$ acrylamide respectively; gel was 180 $\times 200 \times 1.2 \mathrm{~mm}$ ) and run at $20 \mathrm{~mA}$ for $3.5 \mathrm{~h}$. The gel was washed for $1 \mathrm{~h}$ in 1 litre of $2.5 \%$ aqueous Triton $\mathrm{X}-100$ with constant agitation and rinsed repeatedly with distilled water before applying to a $1.3 \mathrm{~mm}$ thick fibrin agarose layer (Kabi fibrinogen, either containing plasminogen or depleted of plasminogen on lysine-Sepharose ${ }^{15} 2 \mathrm{mg} / \mathrm{ml}$; thrombin $0.06 \mathrm{U} /$ $\mathrm{nml}, 17 \cdot 5 \mathrm{mM} \mathrm{NaCl}, 60 \mathrm{mM}$ Tris $\mathrm{pH} 7 \cdot 8,0 \cdot 8 \%$ agarose; final concentrations). After incubation overnight at $37^{\circ} \mathrm{C}$ the polyacrylamide gel was removed and the fibrin agarose layer, with activity apparent as bands of lysis, was photographed. When required, immunoglobulin to tissue type plasminogen activator or to urokinase (generously provided by Dr S Cederholm-Williams, John Radcliffe Hospital, Oxford) was incorporated into a section of the fibrin agarose gel.

\section{PATIENTS}

Eleven patients with alcoholic hepatic cirrhosis were studied. The diagnosis was established on the basis of a clear history, with physical signs and serum biochemistry typical of advanced hepatocellular damage and with liver biopsy features indicative of this diagnosis. All had haemorrhagic features of varying degrees of severity, ranging from cutaneous purpura to recent major gastrointestinal bleeding.
Results

Results of the laboratory investigations on the patients are summarised in the Table. All had evidence of active fibrinolysis, with lysis of fibrin plates by unfractionated plasma, in contrast to normal plasma. Euglobulin lysis time was variable between fast and normal. Plasma concentrations of $\alpha_{2-}$ antiplasmin and antithrombin III were low. Histidine rich glycoprotein concentration was low in most of the patients. Other plasma protease innibitors, $\mathrm{Cl}$ inactivator, $\alpha_{2}$-macroglobulin, and $\alpha_{1}$-antitrypsin, were normal or raised. Plasma plasminogen concentrations were low, while values for fibrinogen were normal.

No complex of $\alpha_{2}$-antiplasmin was found. This contrasts with other conditions with comparably low $\alpha_{2}$-antiplasmin concentrations and similarly enhanced activity on fibrin plates, such as disseminated intravascular coagulation or primary hyperfibrinolysis (Fig. 1). ${ }^{131418}$ Crossed immunoelectrophoresis of $\alpha_{2}$-antiplasmin with plasminogen incorporated into the gel was normal (Fig. 2), indicating a normal ratio of plasminogen binding and nonbinding forms.

Plasma samples were analysed on SDS-PAGE, followed by zymography. Fig. 3 shows the pattern of plasminogen activator activities; the patients' plasma samples showed increased plasminogen activator activities compared with normal plasma. The major bands of activity in cirrhotic plasma had molecular weights of about 50 and $95 \mathrm{~K}$. These bands could be inhibited by antisera to tissue type plasminogen activator or to urokinase (Fig. 4); the $50 \mathrm{~K}$ band was related to urokinase while all the other activities, including the $95 \mathrm{~K}$ band, were related to tissue type plasminogen activator.

Plasma from normal subjects and from patients

Results of laboratory investigations on the patients

\begin{tabular}{|c|c|c|c|c|c|c|c|c|c|c|}
\hline Patient & $\begin{array}{l}\text { Albumin } \\
(\mathrm{g} / \mathrm{l})\end{array}$ & $\begin{array}{l}\text { British } \\
\text { corrected } \\
\text { ratio }\end{array}$ & $\begin{array}{l}\text { Platelet count } \\
\left(\times 10^{4} / l\right)\end{array}$ & $\begin{array}{l}\text { Euglobulin } \\
\text { lysis time } \\
\text { (min) }\end{array}$ & $\begin{array}{l}\text { Plasma fibrin } \\
\text { plate lysis } \\
\text { (mm diam) }\end{array}$ & $\begin{array}{l}\alpha \text {-antiplasmin } \\
(\% \text { normal })\end{array}$ & $\begin{array}{l}\text { Antithrombin } \\
\text { III (\% normal) }\end{array}$ & $\begin{array}{l}\text { Histidine } \\
\text { rich } \\
\text { glycoprotein } \\
\text { (\% normal) }\end{array}$ & $\begin{array}{l}\text { Fibrinogen } \\
(m g / 100 m l)\end{array}$ & $\begin{array}{l}\text { Plasminogen } \\
\text { (\% normal) }\end{array}$ \\
\hline $\begin{array}{l}1 \\
2 \\
3 \\
4 \\
5 \\
6 \\
7 \\
8 \\
9 \\
10 \\
11 \\
\text { Normal } \\
\text { controls }\end{array}$ & $\begin{array}{l}23 \\
23 \\
25 \\
30 \\
27 \\
29 \\
35 \\
28 \\
23 \\
33 \\
30\end{array}$ & $\begin{array}{l}2.3 \\
1.6 \\
3 \cdot 1 \\
1.3 \\
1.5 \\
1.5 \\
1.5 \\
2.5 \\
2.2 \\
1.1 \\
1.0\end{array}$ & $\begin{array}{r}100 \\
112 \\
90 \\
122 \\
52 \\
50 \\
162 \\
134 \\
279 \\
177 \\
125\end{array}$ & $\begin{array}{r}140 \\
140 \\
220 \\
240 \\
180 \\
75 \\
55 \\
55 \\
300 \\
>360 \\
265\end{array}$ & $\begin{array}{c}10 \cdot 5 \\
11 \\
8 \cdot 5 \\
5 \\
8 \\
10 \\
19 \\
17 \\
8 \\
5 \\
5\end{array}$ & $\begin{array}{l}33 \\
38 \\
63 \\
44 \\
50 \\
46 \\
46 \\
42 \\
42 \\
66 \\
60\end{array}$ & $\begin{array}{l}14 \\
26 \\
55 \\
52 \\
42 \\
46 \\
46 \\
34 \\
53 \\
61 \\
70\end{array}$ & $\begin{array}{r}25 \\
25 \\
79 \\
125 \\
21 \\
67 \\
61 \\
83 \\
82 \\
158 \\
158\end{array}$ & $\begin{array}{l}383 \\
290 \\
336 \\
204 \\
260 \\
255 \\
315 \\
245 \\
200 \\
430 \\
340\end{array}$ & $\begin{array}{l}23 \\
38 \\
48 \\
43 \\
28 \\
65 \\
74 \\
38 \\
50 \\
78 \\
80\end{array}$ \\
\hline
\end{tabular}



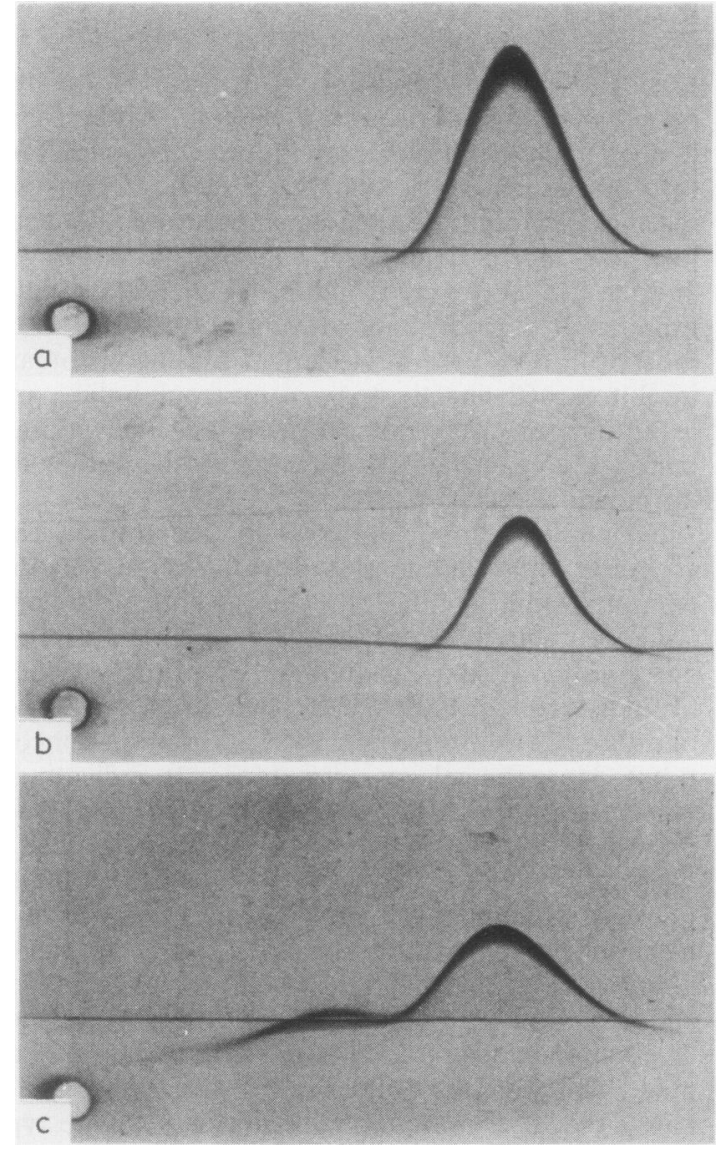

Fig. 1 Crossed immunoelectrophoresis of $\alpha_{2}$-antiplasmin. (a) Normal plasma; (b) plasma from patient 7; (c) plasma from a patient with primary fibrinolysis. ${ }^{18}$

was fractionated on lysine-Sepharose and the fractions assayed for plasminogen activator activity on fibrin plates. Assay by this method showed a single peak of activity, eluted by $1.5 \mathrm{M} \mathrm{NaCl}$, when patients' plasma was fractionated (Fig. 5). No activity was seen by this method when normal plasma was fractionated. The fractions were also analysed by SDS-PAGE and zymography. The fractions from normal plasma contained $95 \mathrm{~K}$ tissue type plasminogen activator in both the unbound peak and the $1.5 \mathrm{M} \mathrm{NaCl}$ eluate (data not shown). The unbound fractions from patients' plasma contained both $50 \mathrm{~K}$ urokinase related activity and tissue type plasminogen activator related activity of molecular weight $95 \mathrm{~K}$ and lower (Fig. 5). The activity eluted with $1.5 \mathrm{M} \mathrm{NaCl}$ consisted mainly of $95 \mathrm{~K}$ and $65 \mathrm{~K}$ material with a minor band of about $160 \mathrm{~K}$. All these bands were related to tissue type plasminogen

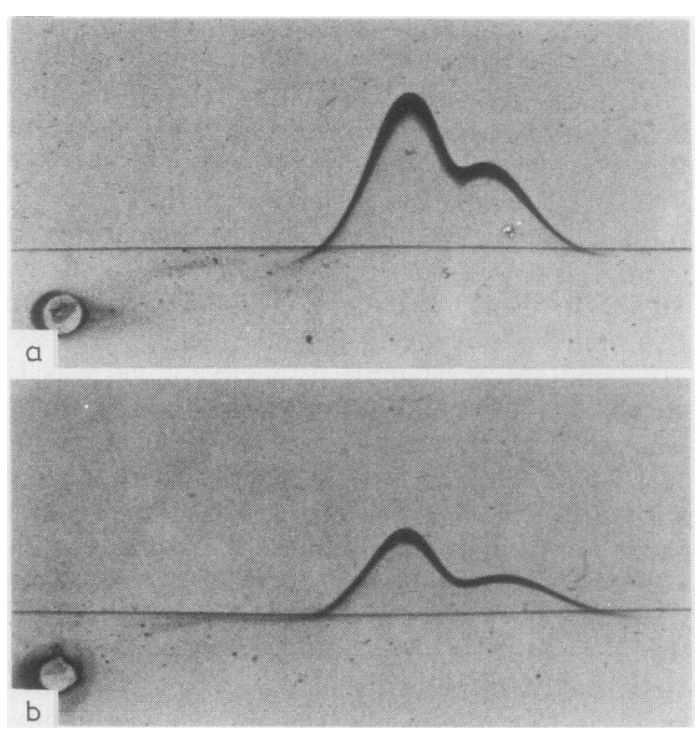

Fig. 2 Crossed immunoelectrophoresis of $\alpha_{2}$-antiplasmin with plasminogen in the first dimension. (a) Normal plasma (b) plasma from patient 7 .

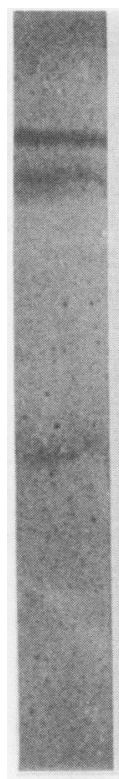

a

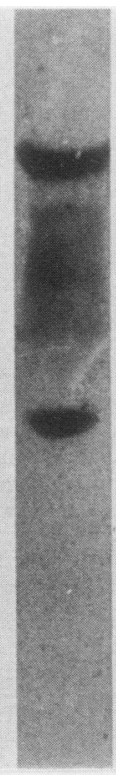

b

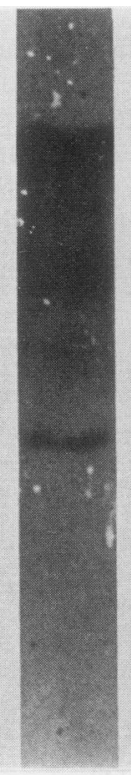

C d

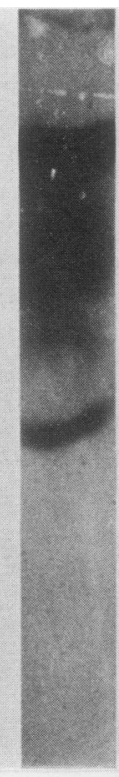

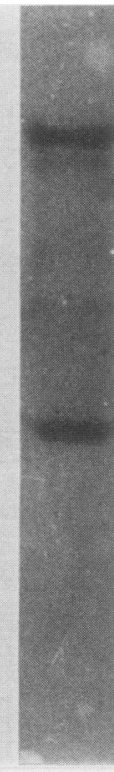

e
Fig. 3 Plasma samples analysed by SDS-PAGE and zymography. (a) Normal plasma; $(b, c, d, e)$ plasma from patients 1, 3, 5, and 6 respectively. 


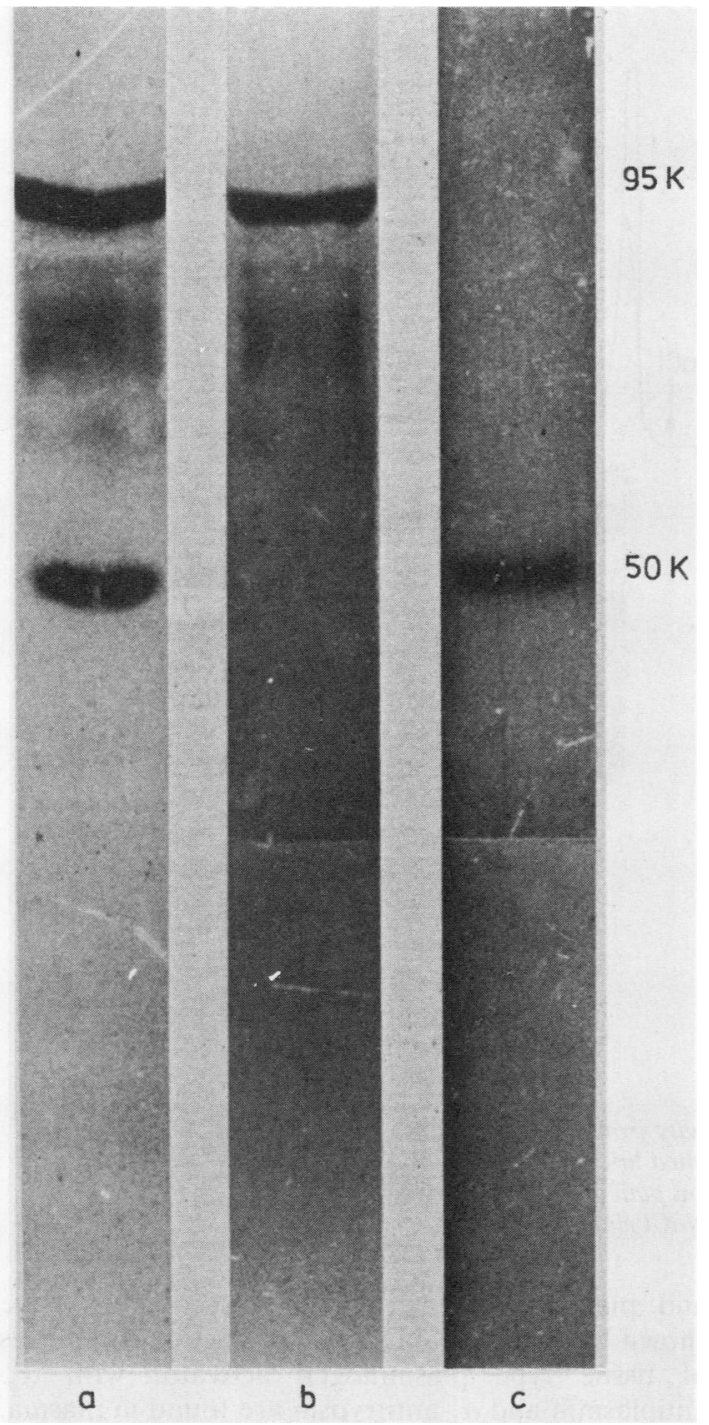

Fig. 4 Plasma from 1 patient analysed by SDS-PAGE and zymography: inhibition by $\gamma$-globulins to urokinase type plasminogen activator and tissue type plasminogen activator incorporated in the fibrin agarose gel. (a) No r-globulin; (b) $\gamma$-globulin to urokinase type plasminogen activator; (c) $\gamma$-globulin to tissue type plasminogen activator.

activator. All the activity eluted from the lysineSepharose column was dependent on the presence of plasminogen; fibrin agarose layers prepared with plasminogen free fibrinogen showed no lysis.

\section{Discussion}

Plasma fibrinolytic activity is increased in patients with alcoholic cirrhosis. The mechanism underlying this increase remains open to debate. There is evidence that the liver has a role in the clearance of plasminogen activator from the circulation ${ }^{321}$ and slow clearance of activator in cirrhotic patients is one explanation for the high fibrinolytic activity in their plasma. Alternatively, low concentrations of inhibitors of the fibrinolytic system, $\alpha_{2}$-antiplasmin and histidine rich glycoprotein, have been suggested as a cause of the increase in fibrinolytic activity. ${ }^{46722}$

In this study the question of increased plasma concentrations of plasminogen activator in liver disease was re-examined in the light of current knowledge of the various types of plasminogen activator which exist in blood. The high plasma concentrations of plasminogen activator, noted previously in hepatic cirrhosis, ${ }^{32}$ were confirmed, and the study was extended to examine the nature of the activator(s) present. The earlier studies measured overall concentrations of plasminogen activator and did not discriminate between different types. Additionally, the methods used previously measured activator in fractions of plasma (prepared specifically to exclude proteins such as protease inhibitors from the assay systems) rather than in whole plasma; this may have excluded material from study. In this study the use of SDS-PAGE with zymography had the advantage of allowing examination of whole plasma. No material was excluded from the system and the different activators were separated from one another and from potential inhibitor proteins in the system itself, allowing demonstration of each plasminogen activator present. The activators in the plasma of the patients studied could be classified as tissue type plasminogen activator or urokinase type plasminogen activator on the basis of inhibition by specific antiserum to these activators. It is clear that both types of plasminogen activator are considerably raised in these patients. Another recent study has shown an increase in tissue type plasminogen activator, ${ }^{24}$ using different techniques, but this is to our knowledge the first demonstration of increased urokinase type plasminogen activator in hepatic cirrhosis.

Separation of plasma plasminogen activators on lysine-Sepharose, followed by assay of the column fractions on fibrin plates, indicates that all the activity of patients plasma was bound to lysineSepharose and could be eluted with $1.5 \mathrm{M} \mathrm{NaCl}$. This is in agreement with Radcliffe and Heinze, ${ }^{14}$ who assayed fractions from post-exercise plasma on fibrin plates and found all the activity in the $1.5 \mathrm{M}$ $\mathrm{NaCl}$ wash. When the fractions from cirrhotic plasma were analysed by SDS-PAGE, followed by zymography, activity was apparent in the unbound fractions as well. The unbound activity included 


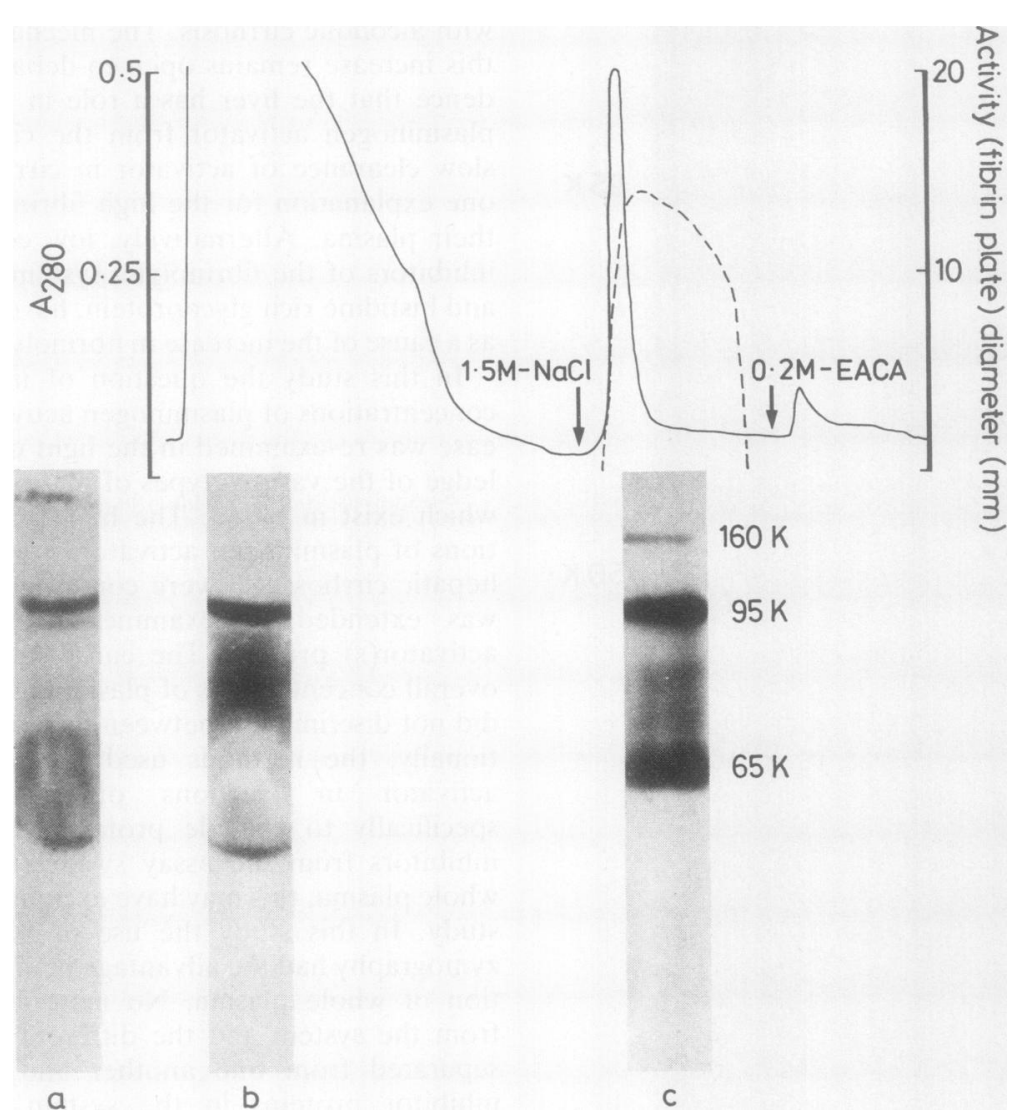

Fig. 5 Elution of plasminogen activator activity from lysine-Sepharose: analysis of plasma from patient 7. Solid line: $A_{280 n m}$; dashed line: activity on fibrin plates. SDS-PAGE and zymography. (a) plasma from patient 7; (b) peak fraction of unbound protein; (c) peak fraction of $1.5 \mathrm{M} \mathrm{NaCl} \mathrm{eluate.}$

urokinase type and tissue type plasminogen activators. These activities may be masked by inhibitors which are also unbound, so that no plasminogen activator activity is observed on fibrin plates. In the case of the tissue type plasminogen activator another interpretation is possible. Since this material has a molecular weight of about $95 \mathrm{~K}$, it may represent a complex which is inactive on fibrin plates but is reactivated under the conditions used for zymography, possibly by exposure to Triton $\mathrm{X}-100 .{ }^{25}$

The fractions eluted from lysine-Sepharose with $1.5 \mathrm{M} \mathrm{NaCl}$ were active on fibrin plates. On analysis by SDS-PAGE and zymography the activity was all related to tissue type plasminogen activator. From the molecular weights of $65 \mathrm{~K}, 95 \mathrm{~K}$, and $160 \mathrm{~K}$, it seems likely that these are due to free tissue type plasminogen activator $(65 \mathrm{~K})$ and to two species of complex between tissue type plasminogen activator and plasma proteins. Rijken and others ${ }^{26}$ have shown by other techniques that inactive complexes of tissue type plasminogen activator with $\alpha_{2^{-}}$ antiplasmin and $\alpha_{1}$-antitrypsin are found in plasma. The species of tissue type plasminogen activator which we have observed may be due to such complexes or to complexes with other inhibitors such as antiactivator. ${ }^{27}$

Early studies indicated that overall plasma inhibition of fibrinolysis was reduced in cirrhotic patients. $^{322}$ Subsequent studies have separately shown reduced levels of plasma $\alpha_{2}$-antiplasmin, ${ }^{4}$ antithrombin III, ${ }^{28}$ and histidine rich glycoprotein. ${ }^{67}$ The level of plasma plasminogen was also decreased..$^{322}$ In this study, we have seen this range of changes in the plasma proteins of cirrhotic patients and have confirmed that striking decreases in $\alpha_{2}$-antiplasmin, antithrombin III, histidine rich glycoprotein and plasminogen occur. Our findings 
indicate that in contrast to these reduced levels, the levels of the inhibitors $\alpha_{2}$-macroglobulin, $\alpha_{1-}$ antitrypsin, and $\mathrm{Cl}$ inactivator are normal or raised.

Despite the high level of plasminogen activator and the reduction of $\alpha_{2}$-antiplasmin concentration seen in this study, we found no evidence of plasmin generation in the circulation, as judged by crossed immunoelectrophoresis against antiserum to $\alpha_{2^{-}}$ antiplasmin, which can detect the generation of complexes between plasmin and $\alpha_{2}$-antiplasmin. ${ }^{13}{ }^{24}$ While this technique is relatively crude, it has been capable of demonstrating plasmin generation in other groups of patients with similarly reduced plasma concentrations of $\alpha_{2}$-antiplasmin and comparable overall fibrinolytic activity. ${ }^{141830}$ This raises questions about the control of fibrinolysis in cirrhotic patients and indicates that while these patients may have a high potential for plasmin generation, owing to high levels of plasminogen activator and low $\alpha_{2}$-antiplasmin concentrations, little such generation of plasmin actually occurs in the circulating blood, in contrast with the situation seen in other disorders. ${ }^{14} 1830$

This study was supported by the Medical Research Council. We thank Dr P Brunt and Dr A Mowat for allowing us to study their patients. We also thank Ms Susan Beattie and Ms Fiona Wheatley for skilled technical assistance.

\section{References}

' Goodpasture EW. Fibrinolysis in chronic hepatic insufficiency. Bulletin of the Johns Hopkins Hospital 1914;25:330-6.

: Ratnoff OD. Studies on a proteolytic enzyme in human plasma IV. The rate of lysis of plasma clots in normal and diseased individuals, with particular reference to hepatic disease. Bulletin of the Johns Hopkins Hospital 1949;84:29-42.

${ }^{3}$ Fletcher AP, Biederman O, Moore D, Alkjaersig N, Sherry S. Abnormal plasminogen-plasmin system activity (fibrinolysis) in patients with hepatic cirrhosis: its cause and consequences. $J$ Clin Invest 1964;43:681-95.

+Aoki N, Yamanaka T. The $\alpha_{2}$-plasmin inhibitor levels in liver diseases. Clin Chem Acta 1978;84:99-105.

' Lijnen HR, Hoylaerts M, Collen D. Isolation and characterization of a human plasma protein with affinity for the lysine binding sites in plasminogen-role in the regulation of fibrinolysis and identification as histidine-rich glycoprotein. $J$ Biol Chem 1980;225: 10214-22.

- Lijnen HR, Jacobs G, Collen D. Histidine-rich glycoprotein in a normal and clinical population. Thromb Res 1981;22:519-23.

${ }^{7}$ Saito H, Goodnough LT, Boyle JM, Heimburger N. Reduced histidine-rich glycoprotein levels in plasma of patients with advanced liver cirrhosis. Am J Med 1982;73:179-82.

${ }^{*}$ Granelli-Piperno A, Reich E. A study of protease and proteaseinhibitor complexes in biological fluids. $J$ Exp Med 1978; 148:223-34.
" Booth NA, Ligertwood Y, Bennett B. Molecular forms of plasminogen activator in human plasma. Progress in Fibrinolysis 1983;6:54-7.

10 Ogston CM, Ogston D. Plasma fibrinogen and plasminogen levels in health and ischaemic heart disease. $J$ Clin Pathol 1966; 19:352-6.

"Ratnoff OD, Menzie C. A new method for the determination of fibrinogen in small samples of plasma. J Lab Clin Med 1951;37:316-20.

${ }^{12}$ Laurell C-B. Quantitative estimation of proteins by electrophoresis in agarose gel containing antibodies. Anal Biochem 1966; 15:45-52.

${ }^{13}$ Booth NA, Bennett B. Plasmin- $\alpha_{2}$-antiplasmin complex as an indicator of in vivo fibrinolysis. Br J Haematol 1982;50:53741.

${ }^{14}$ Booth NA, Bennett B. Plasmin- $\alpha_{2}$-antiplasmin complexes in bleeding disorders characterized by primary or secondary fibrinolysis. Br J Haematol 1984; 56:545-56.

is Deutsch DG, Mertz ET. Plasminogen: purification from human plasma by affinity chromatography. Science $1970 ; 170$ : 1095-6.

${ }^{16}$ Kluft C, Los N. Demonstration of two forms of $\alpha_{2}$-antiplasmin in plasma by modified crossed immunoelectrophoresis. Thromb Res 1981;21:65-71.

17 Mackie M, Booth NA, Bennett B. Comparative studies on human activators of plasminogen. $\mathrm{Br} J$ Haematol 1981;47:77-90.

${ }^{18}$ Booth NA, Bennett B, Wijngaards G, Grieve JHK. A new life long hemorrhagic disorder due to excess plasminogen activator. Blood 1983;61:267-75.

${ }^{14}$ Radcliffe $\mathrm{R}$, Heinze T. Isolation of plasminogen activator from human plasma by chromatography on lysine-Sepharose. Arch Biochem Biophys 1978; 189: 185-94.

${ }^{20}$ Laemmli UK. Cleavage of structural proteins during assembly of the head of bacteriophage T4. Nature 1970;227:680-5.

${ }^{21}$ Korninger C, Stassen JM, Collen D. Turnover of human extrinsic (tissue-type) plasminogen activator in rabbits. Thromb Haemostas 1981;46:658-61.

22 Purcell G, Phillips LL. Fibrinolytic activity in cirrhosis of the liver. Surg Gynecol Obstet 1963;117:139-44.

${ }^{23}$ Ogston D, Bennett B, Ogston CM. The fibrinolytic enzyme system in hepatic cirrhosis and malignant metastases. $J$ Clin Pathol 1971;24:822-6.

${ }^{24}$ Juhan-Vague I, Rijken DC, DeCock F, Mandez C, Collen D. Extrinsic plasminogen activator levels in clinical plasma samples. Progress in Fibrinolysis 1983;6:65-9.

is Schleuning W-D. The plasminogen activators in pooled human plasma. Progress in Fibrinolysis 1983;6:39-42.

${ }^{26}$ Rijken DC, Juhan-Vague I, Collen D. Complexes between tissue-type plasminogen activator and proteinase inhibitors in human plasma, identified with an immunoradiometric assay. $J$ Lab Clin Med 1983;101:285-94.

${ }^{27}$ Kruithof EKO, Ransijn A, Tran-Thang C, Bachmann F. Characteristics of a fast-acting inhibitor of plasminogen activator in human plasma. Thromb Haemostas 1983;50: 193.

${ }^{2 *}$ Hedner U, Nilsson I-M. Antithrombin III in a clinical material. Thromb Res 1973;3:631-41.

${ }^{24}$ Müllertz S, Clemmensen I. The primary inhibitor of plasmin in human plasma. Biochem $J$ 1976; 159:545-53.

${ }^{30}$ Booth NA, Buckler PW, Dawson AA, Ah-See AK, Bennett B. Haemorrhage associated with large abdominal aneurysms. Clin Lab Haematol 1984 (in press).

Requests for reprints to: Dr Nuala Booth, Department of Medicine, Aberdeen Royal Infirmary, Foresterhill, Aberdeen AB9.2ZB, Scotland. 